\title{
イワジリン乾食中毒に関する研究
}

\section{Studies on the Foodpoisoning Caused by Iwashi-Mirinboshi (Japanese)}

\author{
千葉大学腐敗研究所腐敗研究部 \\ 柳沢文德林、充豊浦秀世 \\ 宮林 晃 木村康正 \\ Fumiyoshi Yanagisawa Makoto Hayashi Hideyo Toyoura \\ Akira Miyabayashi Yasumasa Kimura \\ Institute of Food Microbiology, Chiba University
}

\section{緒 言}

所謂腐敗中责あるい快アレルギー様食中毒と称される 食中毒の研究は, サンマ桜乾食中毒の研究に始まつたの であるが，本中毒の主働原因物質はヒスタミンであると とを, 宮木教授等 ${ }^{12}{ }^{213}$ が指摘された。同教授のとの種の 中毒の発症原因についての見解は, 異常に蓄積されたヒ スタミンと他のアミンの協働作用によつて惹起するので あるとされている。腐敗研究部に抏いては, 中毒検体か ら分離した Proteus morganii が, ヒスタミン異常蓄積 を起す原因細菌であるこ己学確認し，また一方本菌の処 理をもつて製造したサンマ桜乾により，中毒の復元に成 功した。

サンマ桜乾以外の 食品に基くアレルギー 様食中毒例 は, 昭和 28 年 7 月, 熊本市内に招けるサバ煮付缶詰肉に よる85名, 昭和 29 年 8 月19日のソウダガツオ煮付 (川崎 市）による11名の中毒例が確認されているにすぎない。 この種の中毒の原因食となる魚類は, 報告された魚類の みでなく, 赤味, 青色の魚類に执いても発生する可能性 が考えられるのであるが, サンマ桜乾を除くとその中毒 例は少ないようである。

昭和 31 年たまたま，東京都内に括いてイワシミリン乾 によるアレルギー様中毒が発生した。かかる原因食の事 例仗従来確認されて抢らず, 即ち魚類別にみて, 本邦で 初めての中毒例であるとともに，本中毒について種くの 検索劣試及たところ, そのヒスタミン生成の原因細菌方 今まで判明している Proteus morganii に基く中毒でな いであろろという興味ある知見も得られたので，本中毒 を中心として検討字重㸚た研究成績の概略安報告して御 批判を仰ぐ次第である。

\section{実験成績}

\section{1. イワシミリン乾中毒例}

昭和 31 年 3 月 25 日東京都内某所に执いて, 昼食にイワ シミリン乾を摂取（摂取量は判然としないが，大体 1 枚 程度）した一家 4 名（夫婦及ひ子供 2 名）が全員に始い て, 摂取後約30～50分後より，全身発赤，僅かな萇麻疹 (主に顔面) 学主症状乞して他に軽度の頭痛, 酷酊感を 生じたが, 大体 $2 \sim 4$ 時閒後に恃, 上記の症状は消褪する こいう中毒が発生した。本中毒症状は, サンマ桜乾にみ られるいわりるアレルギー様中毒と全くその様相が一致 していた。との一家以外に抬いても同様な発症があつた ものと推定されるが，しかし発生地が商店街であつたこ とと，中毒の確認が遅れたためにその発生状況は不明な 点が多い。

中毒発生者が購入したイワシミリン乾の残品は入手で きなかつたが，患者の購入先の食品販売店にある残品 4 枚（1枚25〜35 g，イワシ16匹をもつて1枚となつてい る）を入手するとさができた。東京都市場検查場の調 査によれば，との製品快千葉県片貝にて昭和 31 年 3 月 4 日製造した製品であつた。

\section{2. 検体に関する検查成綪}

入手した 4 枚のイワシミリン乾について従来のサンマ 桜乾中毒例の研究経験に基き,アレルギー様食中毒であ るという見解のもこに各種の検索を試及た（検体を 1 枚 ごとに $\mathrm{A}, \mathrm{B}, \mathrm{C}, \mathrm{D} る$ 符号をつけて，その個々につ いて検討を実施した)。

検体は官能検查成績ではなんら異常を認めることがて きず，やや乾燥すぎこいう程度であつた。細菌数 ( $1 \%$ 
第 1 表 中毒検体の生苗数, $\mathrm{NH}_{3}-\mathrm{N}$ 量 及びヒスタミン量

\begin{tabular}{|c|c|c|c|c|}
\hline 検查項目 & A & B & C & D \\
\hline 細 菌 数 (g) & \multicolumn{4}{|c|}{532 万 } \\
\hline 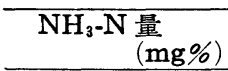 & \multicolumn{4}{|c|}{37.5} \\
\hline $\begin{array}{r}\text { ヒスタミン量 } \\
(\mathrm{mg} / \mathrm{g})\end{array}$ & 4.8 & 4.8 & 1.6 & 3.2 \\
\hline
\end{tabular}

葡萄糖加普通寒天使用), 細菌分布 (山羊血液平板寒天 使用)及び塩基性アンモニ倥素量 $\left(\mathrm{NH}_{3}-\mathrm{N}\right.$ 量) は， 4

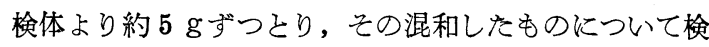
査した。更にヒスタミンの定量は，各サンプルにつき宮 木教授等のルッター法により測定した。官能検査では症 とんぞ異常は認められないが， $\mathrm{NH}_{3}-\mathrm{N}$ 量からみた鮮 度の判定によると，37.5mg\%であることょり不良品とは いえないが，細菌数は 532万/gでやや多いといえる（第 1 表)。な抢 $\mathrm{pH}$ 涪 6.6 ～6.8の範囲にあつた。また血液 寒天平板上に扔ける出現細菌の分布は, 第 2 表に示すこ とくで，特殊な細菌叢は見出しえなかつた。ヒスタミン 量は検体により異なり，最高 $4.8 \mathrm{mg} / \mathrm{g}$ より最低 $1.6 \mathrm{mg} / \mathrm{g}$ の範囲にあつた(第 1 表)。な捈体中に存在するアミノ 酸, アミン類を検討する意味でペーパークロマトグラフ ィーによる検索を実施した。即ち塩酸メタノール抽出物 質について，ペーパークロマトグラムによる分析を試み たのであるが，その検索されたスポット訬第 1 図のでと くであり，その中顕著にヒスタミンの存在を認められ るほか, いくつかのスポットを認めた（濾紙虫東洋濾紙

\section{第1図 ペーパークロマトグラムによる分析}
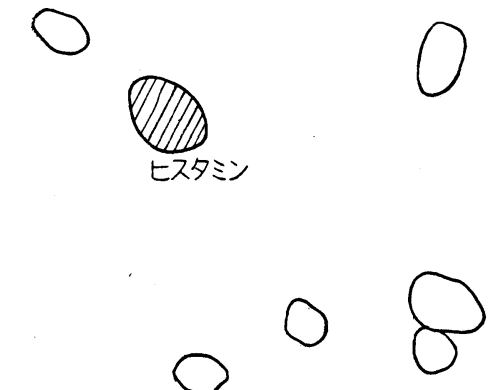

$-7 \pm 1-11$
No. 50, ブタノール 醋酸 (ブタノール 4 , 醋酸 1 , 水 2), フェノール $(80 \%$ フェノール) に上る三次展開後 にニンヒドリン試薬で発色)。

大体サンマ桜乾中毒の検体, あるいは実験的に製造し たサンマ桜乾では, $3.2 \mathrm{mg} / \mathrm{g}$ 以上のヒスタミン量が存在 しているときに，25〜35 g 程度の摂取で発症するという 経験から， $\mathrm{C}$ 検体を除き，大体ヒスタミン量より推定す る己, 入手したイワシミリン乾は, 発症原因食品となり うると考えられる。

\section{3. 検查検体が中毒原因検体であるかの確認}

入手したイワシミリン乾が中毒検体であるか否かにつ いて検討する意味で一応 B 検体を用いて動物実験を実施 した。即ち，塩酸メタノールで抽出した浸出液を蒸発皿 で濃縮乾固した後に, 溜水で抽出し, ェーテルで脱脂し た粗毒についてモルモットの皮下注射による毒性試験を 試みた（粗毒液の材料 $\mathrm{g}$ 当りに対しての毒性を示す）。

検体量に換算して $1.0 \mathrm{~g} ， 0.3 \mathrm{~g}$ をルモット 3 匹ず つ任皮下注射の結果, $1.0 \mathrm{~g}$ 注射群はいずれも注射直後 より不安状態になり, 四肢麻㾝が起り, 呼吸困難状態て $5 \sim 7$ 分で整死した。 $0.3 \mathrm{~g}$ 注射は排尿, 排便をして, 興舊状態を起し，やはり15分後で獘死した。この所見は サンマ桜乾中毒の場合と同様であつた。

更にA及び B 検体の $25 \mathrm{~g}$ を 28 才男子に米飯とをもに摂 取せしめたととろ, 10 分後に顔面の発赤紅潮, 軽度の頭 痛をきたし，顔面の発赤は全身に及ぶも萇麻疹は認めな 亦つた。症状は30分後から漸次消裉し，90分後には医上 んど自他覚症状がなくなり，恢復した。以上 1 例である が貴重な摂食試験成績と動物実験より，検討を重悋てい る検体注明らかに中毒を発症せしめた検体であるという ことを確認した。

\section{4. ヒスタミン生成菌について}

本検体にヒスタミンが異常に蓄積していることが確認 されたので，とのヒスタミンを生成する微生物に関し検 討した。

4 枚のサンプルの混合物を隇菌食塩水にいれ，よく振 盪し，その 1 白金耳を山羊血液寒天平板にコンラジー棒 で塗布して好気的培盖 $\left(27^{\circ} \mathrm{C}\right)$, 嫌気的培養 $\left(37^{\circ} \mathrm{C}\right)$ を実施 した。培養平板より出現した集落を釣菌した後，生物性 状の検查を䒠施して Bergey's manual (1948)の分類に 従つて分類を試みたうえ，菌の分布学求めた。好気培養 平板の分離菌株の分布は第 2 表に示すどとく主要細菌は Micrococcus 属, Enterococcus 属及び酵母であつた。 嫌気的培養办引梳，偏性嫌気性細菌として球菌を 1 株分 
第 2 表 細菌分布 (山羊血液平板による)

\begin{tabular}{|c|c|c|}
\hline $\begin{array}{l}\text { 分離菌株数及びヒスタミン } \\
\text { 菌 種 } \\
\text { 生成有無 }\end{array}$ & 株数 $(\%)$ & $\begin{array}{l}\text { ヒスタ } \\
\text { ミン生 } \\
\text { 成有無 }\end{array}$ \\
\hline Streptococcus faecalis & $6(14.6)$ & - \\
\hline Micrococcus epidermidis & $8(19.5)$ & - \\
\hline Micrococcus auranticus & $10(24.4)$ & - \\
\hline Micrococcus citreus & $2(4.9)$ & - \\
\hline Micrococcus candidus & $4(9.8)$ & - \\
\hline Micrococcus pyogenes var. albus & $1(2.4)$ & - \\
\hline Aerobacter & $2(4.9)$ & - \\
\hline Hefe & $8(19.5)$ & - \\
\hline
\end{tabular}

離した。

分離菌41株についてヒスタミン生成の有無を検討した が，1株もヒスチジンょりヒスタミンを生成する菌株を 認めることができなかつた。

著者等がサンマ榽乾中毒（浜松市の事例）の原因菌で 亦つた Proteus morganii 分離した経験に执いても, 普通平板分離法により原因菌を分離すること法極めて困 難であつた。即ち製造後日数を経た材料の場合に㤝ヒス タミン生成菌の付着菌量が極めて少ないといえる。本検 体の場合も Proteus morganii が付着してヒスタミンが 生成されたものと想定して, S.S.-broth に検体 2.0 3.0 gを入れて, 増菌法を実施した後に, S. S.-agar,

E. M. B.-agar にて分離して, ヒスタミン生成菌の分離 を試みた。その時の検体別に久た出現菌の状沉岎第 3 表 に忩すごとくであつた。即ち Proteus 属, Escherichia 属, Aerobacter 属, Acromobacter 属で者つた。

本分離菌株に怙けるとスタミン生成菌洨, Escherichia 属に含まれるものの及で, 検体 $\mathrm{B}$ を除く 3 検体より 4 株 (No. $3 \mathrm{~A}$, No. $8 \mathrm{~A}$, No. $4 \mathrm{C}$, No. $2 \mathrm{D}$ ) を分離卞子 ことができた。 Proteus 属も分離できたが, 菌種㤃, Proteus vulgaris, Proteus mirabilis $て$, Proteus morganii は検出されなかつた。ヒスタミン生成の Escherichia 属㤝いずれも同一生物性状を示し, 第 4 表

\section{第 3 表 細菌分布 (S.S.-broth 增菌更に} S.S.-agar 分離)

\begin{tabular}{l|l|l|l|l}
\hline \multicolumn{1}{|c|}{ 検 体 } & A & B & C & D \\
菌 株 & 3 & 3 & 4 & 4 \\
Proteus vulgaris & 4 & 1 & 5 & 3 \\
Proteus mirabilis & 2 & 0 & 1 & 1 \\
Escherichia & 2 & 2 & 1 & 1 \\
Aerobacter & 1 & 0 & 0 & 0 \\
Achromobacter &
\end{tabular}

第 4 表 No. $3 \mathrm{~A}$ 株の生物性狀

\begin{tabular}{|c|c|c|c|}
\hline 一 & 般 & 状 & \\
\hline 形態 & $\begin{array}{l}\text { 桿菌 }(0.5 \times 1.5) \\
1.0 \sim 1.5\end{array}$ & 硫 化 水 素 & - \\
\hline グラ ム染色 & 陰 性 & グル & $\oplus$ \\
\hline 動性 & + (周毛) & ラクトーゼ & $\oplus$ \\
\hline V. P. 反 応 & - & マルトーゼ & $\oplus$ \\
\hline M. R. 試 験 & + & キシローゼ & $\oplus$ \\
\hline チトラート培地 & + & アラビノーゼ & $\oplus$ \\
\hline インドール試験 & - & サッカ口ーゼ & 一 \\
\hline 硝酸塩邉 元 & + & グリセリン & - \\
\hline リトマス牛乳 & 酸性 & アドニットール & - \\
\hline ゼラチン液化 & - & & \\
\hline
\end{tabular}

（代表菌としてNo. 3 Aの性状）に示すどとくであつ て, この性状ょり Escherichia intermedium と同定し た。

本菌株No. 3 A, No. 8 A, No. 4 C, No. 2 D てそのヒスチジン脱炭酸醅素能の活性について検討を試 みた。ヒスチジンを添加した一定培養基に増菌した 4 株 の洗條湿菌を，ヒスチジンを添加したフタル酸カリ緩衝 液に作用せしめた際には、ルッター法でいずれもヒスタ ミン陽性の成績を得るととに成功した。上記ヒスタミン 生成汇関する実験法ではヒスチジン脱炭酸醭素能を有す る菌株注自然界に多く存在するが，しかし，サンマエキ ス中でヒスタミンを生成する菌株は少ないととから，各 菌株を魚肉エキスに接種して, ヒスタミンの生成を検討 した。

生イワシの細かく切つた $500 \mathrm{~g}$ に対し溜水 $500 \mathrm{cc} も$ つて, 肉汗をつくる場合と同様な処置により, イワシ浸出 液をつくり, それに葡萄糖を: $1 \%$ 添加して培養基とし た。それらイワシ浸出液に No. $3 \mathrm{~A}$, No. 8 A, No. 4 C, No. 2 D 植えてヒスタミンの定量学試みたとこ ろ, No. $2 \mathrm{D}$ を除き原液で顕著にヒスタミンの存在を認 めたが，No. 2 Dはそれょりもややスポットが小さかつ た。以後 No. 3 A について主に実駼を重补た。イワシ浸 出液中に打ける No. 3 Aのヒスタミン生成状況を Proteus morganii A Yを対照として検討した成績 1 例は第 2 図のごとくであつた。即ち対照の Proteus morganii AY株では著明なヒスタミン産生が認められるが, No. 3 Aではしかし, $1,200 \mathrm{r} / \mathrm{cc}$ (原液の 12 倍稀釈に招いて, ルッター法でヒスタミンを検出し，24倍ではヒスタミン を認めなかつた) 末でルッター法で認められた。即ち No. 3 A について数回同様な実験を重ねたが, 1,200r/cc まで検出した例灶第 2 図に示声場合のみで，以後の実験 


\section{第 2 図 1ワシ浸出液中における AY 株, No. $3 \mathrm{~A}$ 株のヒスタミン生成量と pH の消長}

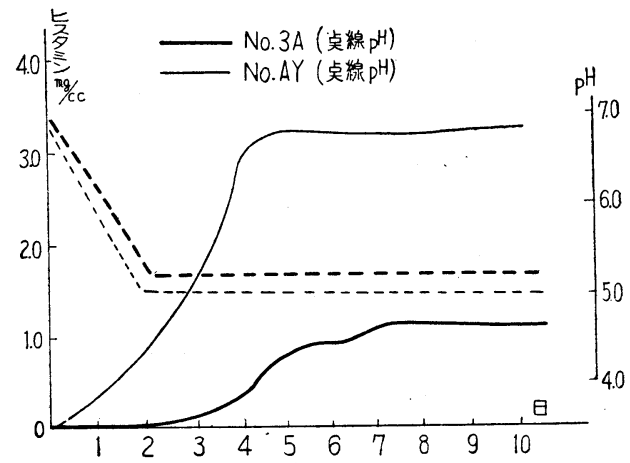

成績では 400 ～ 200 r/cc の範囲で，回を重ねるに従いそ のヒスタミン量は低下し，ある場合には 100 r/cc といる こともあつた。

またNo. $3 \mathrm{~A}$ 株のヒスチジン以外のアミノ酸脱炭酸酵 素作用についてグルタミン酸，アルギニン，オルニチ ン,リジン，チロジン等を検討した結果，アルギニン， $\gamma$-アミノ酢酸のみを生成することを認めた。

またヒスチジン脱炭酸酵素の湿菌の活性学検討するた め, Warburg 検圧計によつて実験した。との場合も前 記実験と同様に Proteus morganii A Y株老対照こして 行つた。その成績は第 3 図のどとくである（菌量は Proteus morganii と同量)。即ち No. $3 \mathrm{~A}$ は A Y 株に 比してその活性は遙に弱いものであることを知つたが, との場合の同一培養菌のイワシ浸出液中の最高ヒスタミ ン生成量は 400 r/ccであつた。

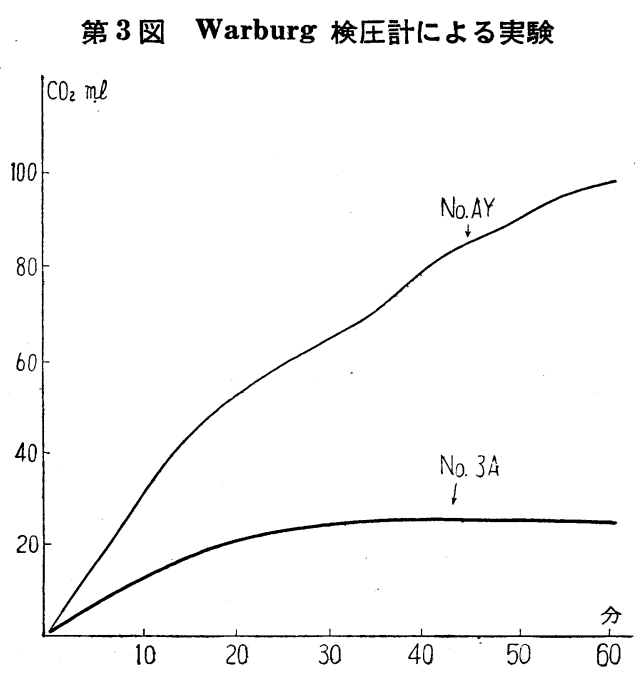

No. $3 \mathrm{~A}$ 株を用い中毒復元検体を製造するととは, 上 記のヒスタミン生成力が弱いととから不可能であると想 像されるが, 一応念のため, No. 3 A 付着のイワシミリ ン乾を製造したととろ，ヒスタミン量は僅かに100～200 $r / g$ 程度であつた。しかしとの際の付着菌の消長を検討 したこころ，製造後においては本菌株は多数分離できた が， $20^{\circ} \mathrm{C}$ 保存にて日数索経るに従い本菌の出現率は低下 し，20日後においては普通平板分離法では本菌の存在が 認められ状態にあつた。 $3 \mathrm{~A}$ 株在用いたイワシミリン 乾の製造後の No. $3 \mathrm{~A}$ 榆体中における菌量恃日字経る に従い減少していくととがみられたのであるが，このこ こは, 著者等が検体より本菌を容易に分離することがで きなかつた一つの裏付け炕なるものと考方られる。

\section{5. イワシミリン乾とアレルギー樣食中毒との関連}

著者が分離したヒスタミン生成菌 Escherichia intermedium が本中毒の原因菌であるか否かの問题は別に 検討するととにして，ミリン乾となる魚類は，サンマ， イワシ，アジ等が主であるので，サンマの場合注解決さ れている関係上検討の必要はないが，イワシ，アジに㧈 いてサンマ桜乾の原因菌 P. morganii AY 株によつて ヒスタミン異常蓄積の加工品ができるか不かの検討起試; みた。ミリン乾の製法は豊浦 (秀世) が別に詳報するの で省略するが，脊開きにしたイワシ（セグロイワシ）, アジを個々に $\mathrm{AY}$ 株を添加した調味液に $27^{\circ} \mathrm{C} て ゙ 24$ 時間浸 漬し:後, $20 \sim 30^{\circ} \mathrm{C} て ゙$ 乾燥 ( 2 日間) して, 充分乾燥後: アラビアコムム塗布して製品とした。数回の実験成績の

\section{第 4 図 実験的中毒イワシ，アジミリン乾 (P. morganii) の細菌数の消長}

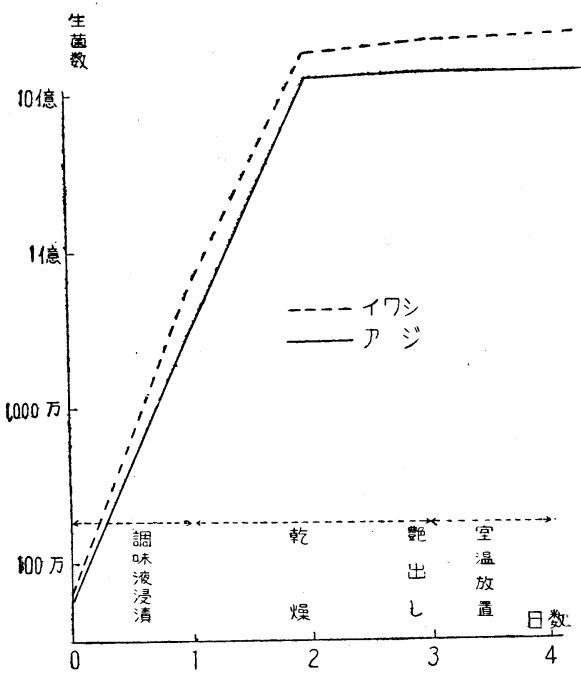


第 5 図 実験的中毒イワシ, アシシミリン乾

(P. morganii) の $\mathbf{N H}_{3}-\mathbf{N}$ 量の消長

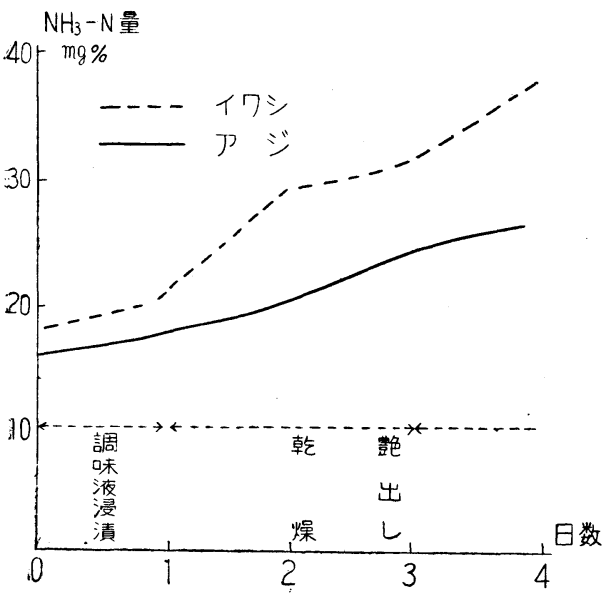

第 6 図 実験的中毒イワジ,アジミリン乾 (P. morganii)の pH，ヒスタミンの消長

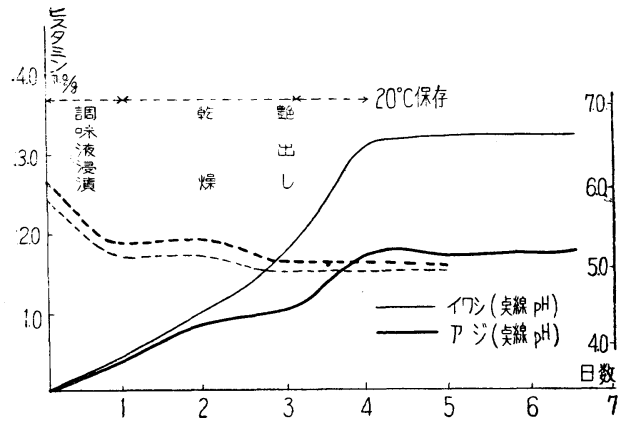

ろち 1 例に打ける細菌数, $\mathrm{pH}, \mathrm{NH}_{3}-\mathrm{N}$ 量及びヒスタミ ン量の状況を第 4 図，第 5 図，第 6 図として示した。細 菌数はイワシ, アジともに浸漬中, 乾燥中に抬いて増殖 して，10億/ g 以上になるが，しかし $\mathrm{NH}_{3}-\mathrm{N}$ 量及びヒ スタミン量はいずれもアジの場合はイワシの場合より下 趈つた状況にあつた。大体サンマ桜乾の実験的中毒例の 場合汴ヒスタミン量が $3.2 \mathrm{mg} / \mathrm{g}$ 以上の存在がないとしろ から考えると，アジのミリン乾で出，イワシの場合より ヒスタミンを中心としたアレルギー様食中毒隹起り難い といえるで㟧う。アジの場合に执いては，ヒスタミン 量が $2.0 \mathrm{mg} / \mathrm{g}$ 以上に認められる場合は, 私共の実験では なかつた。イワシはサンマと同様に，P. morganii のよ うな強力なヒスタミン生成菌が製造時付着すれば,アレ ルギー様食中毒の原因製品となりろる可能が大である。 な扮目下林 (充) は各種魚類につき, P. morganii を用 いて, そのヒスタミンの状況を検討しているが, アジ浸
出エキス中でもヒスタミン産生が低いとと老認めてい る。

\section{考按}

本邦で初めて中毒症例として認められた東京都のイワ シミリン乾食中毒は, 私共の調查及び実験成績によれ ば，明らかにいわゆるアレルギー様食中毒であるとと が確認さ机た。アレルギー様食中毒の主働原因物質で ある異常なヒスタミンを産生する菌が P. morganii で あるということ梳当研究所の研究で初めて明らかにされ たむのである。しかしヒスチジンよりヒスタミンを生成 するアミノ酸脱炭酸酵素を有する菌種の分布は極めて広 いことが判明しているので，ヒスタミンの異常生成 が 必ずしも P. morganii のみによると限定しうる現況に は至つていない。相磯教授等によつて, Escherichia 属で, P. morganii と劣らぬ強い脱炭酸酵素作用を有す る菌株が分離されているととからもいえるのである。本 中表検体からはヒスタミン生成作用が強くかつ安定な P. morganii のごとき菌孝検出するととはできなかつ たが，4検体のきち 3 検体よりヒスタミン生成菌であ る Escherichia intermedium 4 株定分離するととがで きた。しかし，との分離しふ菌株はヒスタミンを生成す るが，各種の実験より中毒検体に認められる淩どのヒス タミン量を生成するととのないととは明らかであり，ま た中毒復元試験もできなかつたので，本菌株が主働原因 物質ヒスタミンを異常に生成する原因細菌と断定すると とはでき難い。しかしとの点につき更に考察を試みてみ る。P. morganii のヒスチジン脱炭酸醏素能が強力であ り，かつその作用が極めて安定で，累代培養によつても 矤こんどその酵素活性孛低下せしめないととは著者等は 経験しているととろであり，また相磯教授等の実験成績 もある671。しかしその反面，ヒスチジン脱炭酸醭素作 用老有する Escherichia coli, Micrococcus 等が分離当 初はその活性が強くても累代培養圭重称ると, その活 性が甚しく低下することも相眏教授等が指摘していると ころである。

これらの点学考慮すれ哚，私共の分離した E. intermedium もとの中毒検体の製造時飞付着したときはヒス チジン脱炭酸酵素作用が強く, 中毒検体となりうるまて のヒスタミン生成作用定有しており, 分離後, 䍕代培養 も実施しているととから，ヒスチジン脱炭酸酵素の活性 が実験時には低下したためにかかる弱い作用の状態に楩 つたのではないかという考虑もできうる。事丰，実験を 重㸚るに従い，分離当初より現在では更に活性が低下 
し，4株中のNo. $2 \mathrm{D}$ はヒスタミンの生成を認められな くなつている。ま分離後最初のヒスタミン生成能の実 験でも 4 株の分離菌株の間にヒスタミンの生成の程度の 差異が認められた。な拝一般好気性腐敗細菌でのヒスタ ミン生成株の分布は広く, ヒスチジン醭母ェキス培地に 增殖させて脱炭酸醭素を産生させた洗條湿菌を，ヒスチ ジン，フタル酸カリ緩衝夜に浮遊させて作用せしめた場 合のヒスタミン検出率恃高いが，しかしその陽性菌株 も, サンマエキスでのヒスタミンの生成は㳘とんど P. morganii に限定されていること学, 豊浦 (秀世) が指 摘している。とのととから考えると, 分離ヒスタミン 生成株はそれらの菌株より一応ヒスタミン生成作用が強 い菌で，特に好条件下でヒスタミンを $1,200 \mathrm{r} / \mathrm{cc}$ 悹で生 成している点を併せ考えると, 比較的特殊な菌株といえ るものとも考えられる。更に先に述べたどとく相機教 授が Escherichia 属の 1 菌株に P. morganii 之同様に 強力なヒスタミン生成を認めた事実も考慮のうちに入れ てもよい。

また本菌株が 4 検体のうち 3 検体から分離しえたと とも本中毒との関連が考慮される。以上のととから本中 绩に打けるヒスタミンの異常蓄樍の原因細菌注 Escherichia intermedium No. $3 \mathrm{~A}$ 等ではないかと推定する 次第である。

な打イワシミリン乾がヒスタミンに基くアレルギー様 食中毒を起しうるものであるか否かを P. morganii を もつて実験した成績によると，サンマ桜乾と同様な条件 で充分中毒原因検体となりうる製品ができるととも明ら かにした。しかしアジのミリン乾では比較的ヒスタミン の生成が減少していることょり, 特殊な場合を除け汸， アレルギー様食中毒は起り難いであろうということも明 らかにした。

\section{総 括}

昭和 31 年 3 月東京都下でイワシミリン乾 (千葉県片貝 町製品) によるいわゆるアレルギー様食中毒の発生があ り，その検体と推定される残品につき，そのヒスタミン
及びその生成菌に関して検討を実施した成績を要約す る。

1）実験に供したイワシミリン乾は中毒発症検体であ るととを，人の摂食試験と，動物実験で確認した。本中 毒の発症状況は全くいわりるサンマ桜乾中毒と同様であ、 つた。

2）検体は官能検查成績及び塩基性アンモニア窒素量 から考慮して，腐敗したものとはいいえないものであつ た。との検体には，ヒスタミンが $4.8 \sim 1.6 \mathrm{mg} / \mathrm{g}$ の範囲 に存在していた。

3）検体より増菌法によりヒスタミン生成菌 4 株を分 離したが，分離菌株はいずれも同一菌種で Escherichia intermedium ですな。しかしそのヒスチジン脱炭酸 酵素の活性注, サンマ桜乾 中毒検体より分離した P. morganii より弱く，かつ安定性がなかつた。

4）本中毒検体のヒスタミン異常生成の原因菌は分離 菌 Escherichia intermedium と推定されるが，しか し累代培養によりヒスタミン生成能が低下するために確 認はできなかつた。

5） P. morganii を用いてイワシミリン乾を実験的に 製造したところ，その製品はアレルギー様食中毒の検体 となりろることができた。

本研究怡昭和 31 年度文部省科学研究費（試験研究） r よつて実施された。な扣本中毒検体の入手及び疫学的調 查に関しては東京都立市場検查所の協力を得た。同検査: 所に対し感謝の意を表する。

\section{主要交献}

1）宮木, 林他：腐敗研究所年報. 6,90 (1954).

2) 宮木, 林他 : 薬学雑誌. 74,1145 (1954).

3) 林 : 薬学雑誌. 74,1148 (1954).

4）相磯，柳沢：日本医事新報。10,1015(1955).

5）柳沢等：腐敗研究所報告. $6,55(1953)$.

6) 相磯等 : 細菌学雑誌. 10,1015 (1955).

7) 相磯等 : 細菌学雑誌. 11,517 (1956)。

（受付：1956年11月12日〉 